\title{
QUANTIFICATION OF DAMAGE AND YIELD LOSSES AND MANAGEMENT OF ROOT-KNOT NEMATODES IN CONILON COFFEE ${ }^{1}$
}

\author{
FERNANDO DOMINGO ZINGER ${ }^{2}$, LILIAN KATIANY CASTELLO RABELLO ZINGER ${ }^{3}$, WILLIAN BUCKER \\ MOARES $^{3}$, GUILHERME DE RESENDE CAMARA ${ }^{3}$, FABIO RAMOS ALVES $^{3 *}$
}

\begin{abstract}
Commercial exploitation of the coffee crop is one of the most important activities in the world's agricultural sector. One of the main phytosanitary problems affecting the crop is the presence of Meloidogyne incognita. Several measures have been tested for the management of this pathogen, albeit with low efficiency. The objective of this work was to quantify the damage and losses and to manage $M$. incognita race 1 with Pochonia chlamydosporia and Trichoderma harzianum biological nematicides, comparing them to a chemical nematicide. The experiment was carried out in a commercial area naturally infested by the nematode and cultivated with the conilon coffee variety 'Vitória INCAPER 8142', clone V02. The treatments were tested with Carbofuran nematicide and with biological nematicides composed of $P$. chlamydosporia Pc-10 and $T$. harzianum ESALQ 1306. The biological products were applied alone or in combination. The lowest NPF (final nematode population) occurred in plants treated with $P$. chlamydosporia and Carbofuran. P. chlamydosporia was the most effective biological agent in the management of $M$. incognita. There was a reduction in production with an increase in the nematode population. The highest application costs of management methods for $M$. incognita race 1 per hectare were for three and two applications of Carbofuran and three applications of $P$. chlamydosporia $+T$. harzianum. The treatments with lowest application costs were one application of $T$. harzianum and one application of $P$. chlamydosporia. It was concluded that all treatments were efficient for the management of $M$. incognita race 1 , causing a decrease in the roots and soil population.
\end{abstract}

Keywords: Conilon coffee. Biological control. Damage. Loss.

\section{QUANTIFICAÇÃOd E DANOS E PERDAS E MANEJO DOS NEMATOIDES DAS GALHAS EM CAFEEIRO CONILON}

RESUMO - A exploração comercial da cultura do café é uma das atividades mais importantes do setor agropecuário mundial. Um dos principais problemas fitossanitários da cultura é a presença de Meloidogyne incognita. Várias medidas têm sido testadas para o manejo desse patógeno, porém, com baixa eficiência. $\mathrm{O}$ objetivo deste trabalho foi quantificar os danos e as perdas e manejar $M$. incognita raça 1 com nematicidas biológicos à base de Pochonia chlamydosporia e Trichoderma harzianum. O experimento foi conduzido em uma área comercial naturalmente infestada pelo nematoide e cultivada com a variedade de café conilon 'Vitória INCAPER 81421', clone V02. Foram testados os tratamentos: nematicida Carbofurano; nematicidas biológicos à base de $P$. chlamydosporia Pc-10 e $T$. harzianum ESALQ 1306. Os produtos biológicos foram aplicados isoladamente ou associados. As menores populações finais de nematoides ocorreram em plantas tratadas com P. chlamydosporia e Carbofurano. P. chlamydosporia foi o agente biológico mais eficaz no manejo de $M$. incognita. Houve redução de produção com o aumento da população do nematoide. Os maiores custos de aplicação dos métodos de manejo para $M$. incognita raça 1 por hectare foram para três e duas aplicações de Carbofuran e três aplicações de $P$. chlamydosporia $+T$. harzianum. Os tratamentos com menores custos de aplicação foram uma aplicação de $T$. harzianum e uma aplicação de $P$. chlamydosporia. Conclui-se que todos os tratamentos foram eficientes para o manejo de $M$. incognita raça 1 , acarretando diminuição da população do nematoide nas raízes e no solo.

Palavras-chave: Cafeeiro conilon. Controle biológico. Danos. Perdas.

\footnotetext{
${ }^{*}$ Corresponding author

${ }^{1}$ Received for publication in $12 / 04 / 2019$; accepted in $02 / 04 / 2021$.

Paper extracted from the doctoral thesis of the first author.

${ }^{2}$ Institutto Federal de Educação Ciência e Tecnologia de Santa Catarina, Campus Lages, Lages, SC, Brazil; fernando.zinger@ifsc.edu.br ORCID: 0000-0003-3552-8895.

${ }^{3}$ Center for Agricultural Sciences and Engineering at the Universidade Federal do Espírito Santo, Alegre, ES, Brazil; lilianzinger01@gmail.com - ORCID: 0000-0002-9780-6822, willian.moraes@ufes.br - ORCID: 0000-0001-7478-7772, camara.gdr@gmail.com - ORCID: 0000-0001-8181-429X, fabioramosalves@yahoo.com.br - ORCID: 0000-0001-8200-2891.
} 


\section{INTRODUCTION}

Espírito Santo is the second most important Brazilian state in coffee production, and the first in the production of Coffea canephora Pierre ex A. Froehner (conilon coffee), in which it stands out as the most economically and socially important agricultural activity for the development of the state (CONAB, 2017).

Phytonematoids are among the main phytosanitary pests causing damage to coffee (CONTARATO et al., 2014). Worldwide, about fifteen species of Meloidogyne spp. have been described as parasites of this crop, with $M$. exigua, M. paranaensis and M. incognita the most harmful ones (OLIVEIRA et al., 2011).

To manage Meloidogyne spp. in the field, synthetic nematicides are generally used; however, due to their high toxicity, risk of environmental contamination and inconsistent field-level results (NASR, 2015), alternative management practices have been researched, such as the use of antagonist fungi (RODRIGUES et al., 2016). Among the fungi with potential use in agriculture for nematode management are Pochonia chlamydosporia Zare \& Gams (syn. Verticillium chlamydosporium Goddard) (VIGGIANO; FREITAS; LOPES, 2014), and Trichoderma harzianum Rifai (MENDOZA et al., 2015).

In the field, to prevent damage to plants caused by Meloidogyne spp., the population of these pathogens should be kept below the economic threshold (ET), defined as the intensity of the disease at which the benefit of control equals its cost. For this, it is critical that damage and yield losses be quantified for this definition to be operational and for integrated management to be viable (ABDELGAWARD; ASKARY, 2015).

Due to the serious problem that $M$. incognita race 1 represents for conilon coffee growing worldwide, this research aimed to quantify the damage and yield losses caused by $M$. incognita race 1 in conilon coffee and to test different strategies of conilon coffee management involving different numbers of applications of biological nematicides based on $P$. chlamydosporia and $T$. harzianum, applied alone and in combination, and the use of a chemical nematicide in plants grown in a commercial area.

\section{MATERIAL AND METHODS}

\section{Characterization of the experimental area}

The experiment was carried out in a commercial field during the months of September
2013 and March 2014, in the municipality of São Roque do Canaã, in the central highlands of Espírito Santo State, with longitude $40^{\circ} 39^{\prime} 17^{\prime \prime} \mathrm{W}$ and latitude $19^{\circ} 45^{\prime} 17^{\prime \prime} \mathrm{S}$; average altitude of $225 \mathrm{~m}$ and rugged topography. The soil was characterized as eutrophic Red Yellow Latosol with good drainage.

According to the Köppen international classification, the climate of the region is of the "Cwa" type, i.e. humid warm tropical with cold and dry winter, with annual average temperature of $24.5^{\circ} \mathrm{C}$ and annual average rainfall of $1,341 \mathrm{~mm}$.

The harvest consisted of a 24-month Conilon coffee bush variety, 'Vitória INCAPER 8142' clone $\mathrm{V} 02$ (at the installation of the experiment), grown in rows, with spacing of $2.80 \mathrm{~m} \times 1.20 \mathrm{~m}$ between rows and plants, respectively. We used five planting lines, chosen because it is a clone widely cultivated in Espírito Santo and very susceptible to $M$. incognita. Confirmation of the species used the methodology of Carneiro and Almeida, (2001). The characterization of race 1 was carried out using the method of Hartman and Sasser (1985).

\section{Experimental design and conduct of the experiment}

The experiment was arranged in the field in randomized blocks in a split plot scheme The area was divided into four blocks, in which each one consisted of five management methods (four nematicides and control) and subplots, with different times of application, drawn within the plot.

The experimental unit consisted of five plants, but three plants were considered useful for analysis. The total number of plants in the experiment was 300 (5 management methods x 3 application numbers x 4 blocks x 5 plants).

The experimental plot consisted of 15 plants divided into 3 subplots, each with 5 plants.

The treatments, doses and times of aplication are listed in Table 1.

For treatments that received two applications, the second was performed 60 days after the first, and for three applications the third took place 60 days after the second.

The first application took place on September 15, 2013, the second on November 15, 2013 and the third on January 15, 2014.

The Carbofuran nematicide: $50 \mathrm{~g} / \mathrm{kg}(5 \% \mathrm{w} /$ w) was manually applied in holes opened in the surface of soil at a depth of $5.0 \mathrm{~cm}$, in the projection of the coffee canopy, and then the biological nematicides were diluted in water and applied manually via backpack.

The management of fertilization, irrigation and other cultural or phytosanitary treatments was performed according to the needs of the crop. 
Table 1. Dosages and methods of application of biological and chemical nematicides for the management of $M$. incognita race 1 , in the conilon coffe variety 'Vitória INCAPER 8142 ' clone V02 in a commercial area naturally infested by the pathogen.

\begin{tabular}{|c|c|c|c|}
\hline & $\begin{array}{l}\text { Recommended dose } \\
\quad(\mathrm{kg} \text { or } \mathrm{L} / \mathrm{ha})\end{array}$ & Dose used per plant & Application means \\
\hline Control & ---------------- & -------------- & ---------------- \\
\hline Carbofurano: $50 \mathrm{~g} / \mathrm{kg} 1^{*}$ & $89.34 \mathrm{~kg} / \mathrm{ha}^{1}$ & $30 \mathrm{~g}$ & Solid/incorporated \\
\hline Carbofurano: $50 \mathrm{~g} / \mathrm{kg} 2$ & $178.68 \mathrm{~kg} / \mathrm{ha}$ & $30 \mathrm{~g}$ & Solid/incorporated \\
\hline Carbofurano: $50 \mathrm{~g} / \mathrm{kg} 3$ & $268.02 \mathrm{~kg} / \mathrm{ha}$ & $30 \mathrm{~g}$ & Solid/incorporated \\
\hline Trichoderma. harzianum: 1 & $1.00 \mathrm{l} / \mathrm{ha}^{2}$ & $200 \mathrm{~mL}$ syrup/plant: $595.61 \mathrm{syrup} / \mathrm{ha}$ & Diluted/squirt \\
\hline T. harzianum: 2 & $2.00 \mathrm{l} / \mathrm{ha}$ & $200 \mathrm{~mL}$ syrup/plant: 595.61 syrup/ha & Diluted/squirt \\
\hline T. harzianum: 3 & $3.00 \mathrm{l} / \mathrm{ha}$ & $200 \mathrm{~mL}$ syrup/plant: $595.61 \mathrm{syrup} / \mathrm{ha}$ & Diluted/squirt \\
\hline Pochonia. chlamydosporia: 1 & $2.00 \mathrm{~kg} / \mathrm{ha}^{3}$ & $200 \mathrm{~mL}$ syrup/plant: $595.61 \mathrm{syrup} / \mathrm{ha}$ & Diluted/squirt \\
\hline P. chlamydosporia: 2 & $4.00 \mathrm{~kg} / \mathrm{ha}$ & $200 \mathrm{~mL}$ syrup/plant: 595.61 syrup/ha & Diluted/squirt \\
\hline P. chlamydosporia: 3 & $6.00 \mathrm{~kg} / \mathrm{ha}$ & $200 \mathrm{~mL}$ syrup/plant: $595.61 \mathrm{syrup} / \mathrm{ha}$ & Diluted/squirt \\
\hline P. chlamydosporia $+T$. harzianum $: 1$ & $2.00 \mathrm{~kg} / \mathrm{ha}+1.00 \mathrm{l} / \mathrm{ha}$ & $200 \mathrm{~mL}$ syrup/plant:5 $95.61 \mathrm{syrup} / \mathrm{ha}$ & Diluted/squirt \\
\hline P. chlamydosporia $+T$. harzianum: 2 & $4.00 \mathrm{~kg} / \mathrm{ha}+2.00 \mathrm{l} / \mathrm{ha}$ & $200 \mathrm{~mL}$ syrup/plant: $595.61 \mathrm{syrup} / \mathrm{ha}$ & Diluted/squirt \\
\hline P. chlamydosporia $+T$. harzianum $: 3$ & $6.00 \mathrm{~kg} / \mathrm{ha}+3.00 \mathrm{l} / \mathrm{ha}$ & $200 \mathrm{~mL}$ syrup/plant: $595.61 \mathrm{syrup} / \mathrm{ha}$ & Diluted/squirt \\
\hline
\end{tabular}

*Each of the treatments was applied once, twice or three times.

\section{Population evaluation of $M$. incognita race 1}

From each repetition, $100 \mathrm{~g}$ roots were collected from each of the three central plants to form a sample composed of $300 \mathrm{~g}$, stored in plastic bags and packed in polystyrene boxes until the moment of the evaluations.

To quantify the nematode population in the root system (eggs + juveniles of second stage, J2), we used the methodology proposed by Hussey and Barker (1973), modified by Bonetti and Ferraz (1981). For the evaluation of the population of nematodes in the soil the extraction was done by the Jenkins technique (1964).

\section{Damage Quantification}

In March, 2014, coinciding with the last nematological evaluation, the following were evaluated: number of fruits per rosette (NFPR); total grain weight per rosette (TGWR) (g); weight of 100 processed grains (g) (WG100); processed (total sample processed coffee weight)/mature yield $(1 \mathrm{~kg})$ (PMY\%).

To estimate NFPR and TGWR, the plagiotropic branches located at the average height of the plants were taken as the basis of calculation. Four branches were collected, one in each quadrant of the plant, and the fruits of the three productive rosettes were counted in the median position of the productive branch, being then weighed in an analytical balance with precision of $0.001 \mathrm{~g}$.

For the evaluation of WG100 and PMY\%, samples of $10.0 \mathrm{~kg}$ of ripe fruits were taken from each treatment and placed in plastic trays, and then taken into sunshine to dry in a plastic oven until reaching a moisture content of $12.0 \%$, and then benefited in a Model DRC-1 peeler.

These processed grains were weighed on an analytical balance accurate to $0.001 \mathrm{~g}$ to obtain the WG100, and the PMY\% by the equation: (total sample processed coffee weight $/ 10.0 \mathrm{~kg}$ ) x 100 .

Yield in bags per hectare (YBHa) calculations were prepared as proposed by Androcioli Filho and Androcioli, (2011), in which:

\section{Mature coffee (kg/ha):}

[No. plagiotropic branches $\mathrm{x}$ no. rosettes $\mathrm{x}$ grain weight per rosette $\mathrm{x}$ no. plants per ha];

$60 \mathrm{~kg}$ bags of processed coffee $/ \mathrm{ha}$ :

[Yield (\%) x productivity of mature coffee)/60]

The value of U\$ 1.00 was considered equivalent to $\mathrm{R} \$ 4.00$ for this search.

The production values (U\$/ha) were obtained by multiplying the productivity, in bags per hectare, by the average price of U\$ 56.50 per bag of $60 \mathrm{~kg}$ of conilon type $7 / 8$ coffee, obtained through the series prices registered by the national supply company, CONAB, from 2003 to 2017 (CONAB, 2017).

Based on these results, the yield gains for each management method were obtained by subtracting the yield obtained in the area for each treatment from the yield obtained in plants that received no treatment (control). The yield value gain, where each management method was applied, was considered in U\$/ha, obtained by subtracting the yield obtained in each plot treated from the plant 
production in the untreated plots.

Based on the production value obtained (U\$/ha) and the application costs of each management strategy (U\$/ha), the net production gain (U\$/ha) was calculated by decreasing the production value of each management method, by their respective application costs, without taking into account the production costs of the crop, which were not accounted for in this calculation.

Sieve classification analyses were performed from a $300 \mathrm{~g}$ sample, according to the size of the sieves, and the sieves were numbered from 10 to 17 for flat and mocha grains, besides residue (BRASIL, 2003)

\section{Yield loss quantification}

Application costs were based on the recommended coffee dosages and the costs of each of the products tested. Dosage and cost calculations per hectare are explained below:

a) Carbofuran: $50 \mathrm{~g} / \mathrm{kg}(5 \% \mathrm{w} / \mathrm{w})$, Furadan ${ }^{\circledR}$ 50 GR commercial product (30.0 grams per plant; recommendation: 2978 plants $/$ ha $\times 0.030 \mathrm{~kg} /$ plant: $89.34 \mathrm{~kg} / \mathrm{ha}$ ), average price per bag of $10 \mathrm{~kg}$ of nematicide in Espírito Santo: U\$ 24.00 (COOPEAVI, 2015);

b) $T$. harzianum biological nematicide, strain ESALQ 1306, recommendation $1.0 \mathrm{~L} / \mathrm{h}$, average price per package of 1 liter in Espírito Santo: U\$ 35.00 (KOPPERT, 2013);

c) Biological nematicide based on $P$. chlamydosporia isolate Pc-10, recommendation 2.0 $\mathrm{kg} / \mathrm{ha}$. Average price per package of $2 \mathrm{~kg}$ in Espírito Santo: U\$ 60.00 (RIZOFLORA, 2013).

In addition to the costs related to each product tested, the labor cost per application was added, which for the conditions tested was U\$ 12.50 per application per hectare.

\section{Statistical analysis}

The data obtained were analyzed using the statistical software "Program GENES", to adjust the statistical models for the mean test at $5 \%$ of significance using the Scott and Knott test. For the results that proceeded to the linear regression analysis, the software SIGMA PLOT ${ }^{\circledR} 11.0$ was used, with the model chosen by the coefficient of determination $\left(\mathrm{R}^{2}\right)$ and significance of the regression coefficient (ß1).

\section{RESULTS AND DISCUSSION}

\section{Population evaluation of $M$. incognita race 1}

Biological nematicides applied alone and in combination caused a decrease in the egg + juvenile of the second-stage ( $\mathrm{J} 2)$ population of $M$. incognita race 1 in plant roots (Table 2 ).

The largest populations of $M$. incognita race 1 were found in roots of untreated conilon coffee (control) (Table 2)

In March, carbofuran was the treatment that most reduced the nematode population with one and two applications, with means that did not differ (Table 2).

The nematode population in the experiment set up in September 2013, considering the average of the four blocks, was 3,000 eggs $+\mathrm{J} 2 / 50 \mathrm{~g}$ of roots and $725 \mathrm{~J} 2 / 100 \mathrm{~cm}^{3}$ of soil. The increase in nematode population from 3,000 to 52,666 eggs + J2/50g from September to November 2013 (Table 2) in control plants can be attributed to the life-cycle characteristics of Meloidogyne spp., in addition to the intense physiological activity of the coffee plant during this period. These caused an increase in the number of rootlets and the release of root exudates by plants, which favors nematode penetration and multiplication (SILVA et al., 2015).

According to Escobar et al. (2015), each female of $M$. incognita can deposit in the region of the cortical parenchyma or on the root surface an egg mass containing on average 400 to 500 eggs. According to Moens, Perry and Starr (2009), the life cycle of $M$. incognita with temperatures around $29^{\circ}$ $\mathrm{C}$ may be only 21 days, and at this stage it is already possible to find egg masses. This indicates that the increase in the coffee root nematode population in the present research, including in plants that received the treatments, is mainly due to the availability of a susceptible host and favorable climatic conditions. The studied coffee crop is located in a region whose climate is characterized as tropical hot and humid, with a cool and dry winter, with an average annual temperature of $24.5^{\circ} \mathrm{C}$, and rain beginning in October and ending in April. These conditions favored the multiplication of the nematode during September to March, the summer season.

The nematode population reductions promoted by the treatments generate knowledge of fundamental importance at a moment of transformation of coffee from Espírito Santo, due to the introduction of new genetic materials.

The fungus $T$. harzianum, applied alone, provided a decrease in NFP (final population) at all evaluated times, with the highest management effectiveness achieved in January with 2 and 3 applications in relation to the control (Table 2). $T$. harzianum also reduced soil final population compared to control in all periods and application quantities (Table 2 ). This proves that $T$. harzianum provides a long-term decrease in the soil nematode population, which is one of the advantages of biological nematode control. The fungus $T$. harzianum is an antagonist that inhibits and blocks 
the development of phytopathogens in the soil, using some mechanisms such as antibiosis, parasitism and competition (MENDOZA et al., 2015). In addition to the direct effects on phytonematodes, T. harzianum also stimulates plant root development, releasing substances called metabolites, which act as phytohormones and resistance inducers, acting on organic matter decomposition and nutrient release (KOPPERT, 2013). Several studies demonstrate that root colonization by Trichoderma spp. has elevated the level of enzymatic defense of plants, including peroxidase, chitinase, $\quad \beta$-1,3-glucanases, lipoxygenase and phenylalanine ammonia lyase (HOWELL et al., 2000).

Table 2. Population of Meloidogyne incognita race 1 (eggs + second-stage juveniles, $\mathrm{J} 2 / 50 \mathrm{~g}$ root) in roots of coffee conilon clone V02 variety 'Vitória INCAPER 8142 ', and in soil $\left(\mathrm{J} 2 / 100 \mathrm{~cm}^{3}\right)$ in an area naturally infested by the pathogen, submitted to different management methods with evaluation at different times.

\begin{tabular}{lcccccc}
\hline & \multicolumn{3}{c}{ Eggs $+\mathrm{J} 2 / 50 \mathrm{~g}$ root } & \multicolumn{3}{c}{$\mathrm{J} / 100 \mathrm{~cm}^{3}$ of soil } \\
\cline { 2 - 7 } \multicolumn{1}{c}{ Treatments } & $\begin{array}{c}\text { November } \\
\text { Control }\end{array}$ & $\begin{array}{c}\text { January } \\
(2013)\end{array}$ & $\begin{array}{c}\text { March } \\
(2014)\end{array}$ & $\begin{array}{c}\text { November } \\
(2013)\end{array}$ & $\begin{array}{c}\text { January } \\
(2014)\end{array}$ & $\begin{array}{c}\text { March } \\
(2014)\end{array}$ \\
\hline Carbofuran: $50 \mathrm{~g} / \mathrm{kg} \mathrm{1*}$ & $52.666 \mathrm{cF}^{1}$ & $54.333 \mathrm{aE}$ & $64.783 \mathrm{bH}^{1}$ & $1.340 \mathrm{bF}^{1}$ & $620 \mathrm{aF}$ & $1.823 \mathrm{cG}$ \\
Carbofuran: $50 \mathrm{~g} / \mathrm{kg} \mathrm{2}$ & $10.246 \mathrm{bB}$ & $11.778 \mathrm{bB}$ & $5.617 \mathrm{aA}$ & $350 \mathrm{cD}$ & $151 \mathrm{aA}$ & $248 \mathrm{bB}$ \\
Carbofuran: $50 \mathrm{~g} / \mathrm{kg} \mathrm{3}$ & $8.800 \mathrm{bA}$ & $15.673 \mathrm{cC}$ & $5.866 \mathrm{aA}$ & $288 \mathrm{bC}$ & $250 \mathrm{bC}$ & $150 \mathrm{aA}$ \\
T. harzianum: 1 & $11.020 \mathrm{aB}$ & $14.365 \mathrm{bC}$ & $14.795 \mathrm{bC}$ & $312 \mathrm{bC}$ & $112 \mathrm{aA}$ & $350 \mathrm{bC}$ \\
T. harzianum: 2 & $32.621 \mathrm{bE}$ & $22.030 \mathrm{aD}$ & $28.362 \mathrm{bG}$ & $418 \mathrm{aD}$ & $468 \mathrm{aE}$ & $710 \mathrm{bF}$ \\
T. harzianum: 3 & $30.000 \mathrm{cE}$ & $14.483 \mathrm{aC}$ & $22.041 \mathrm{bE}$ & $302 \mathrm{aC}$ & $350 \mathrm{bD}$ & $300 \mathrm{aB}$ \\
P. chlamydosporia: 1 & $31.230 \mathrm{cE}$ & $15.255 \mathrm{aC}$ & $21.931 \mathrm{bE}$ & $358 \mathrm{bD}$ & $387 \mathrm{bD}$ & $298 \mathrm{aB}$ \\
P. chlamydosporia: 2 & $14.700 \mathrm{aC}$ & $15.650 \mathrm{aC}$ & $23.681 \mathrm{bF}$ & $412 \mathrm{bD}$ & $122 \mathrm{aA}$ & $634 \mathrm{CE}$ \\
P. chlamydosporia: 3 & $19.800 \mathrm{bD}$ & $8.700 \mathrm{aA}$ & $24.120 \mathrm{bF}$ & $200 \mathrm{aB}$ & $300 \mathrm{bD}$ & $750 \mathrm{cF}$ \\
P. chlamydosporia + T. harzianum: 1 & $20.579 \mathrm{bD}$ & $12.166 \mathrm{aB}$ & $35.320 \mathrm{cG}$ & $156.0 \mathrm{aA}$ & $456.0 \mathrm{bE}$ & $440.0 \mathrm{bD}$ \\
P. chlamydosporia + T. harzianum: 2 & $22.130 \mathrm{bD}$ & $9.276 \mathrm{aA}$ & $20.744 \mathrm{bD}$ & $450.0 \mathrm{bE}$ & $250.0 \mathrm{aC}$ & $522.0 \mathrm{cE}$ \\
P. chlamydosporia + T. harzianum: 3 & $21.200 \mathrm{bD}$ & $9.543 \mathrm{aA}$ & $19.153 \mathrm{bD}$ & $370.0 \mathrm{bD}$ & $275.0 \mathrm{aC}$ & $532.0 \mathrm{cE}$ \\
\hline
\end{tabular}

${ }^{1}$ Averages followed by the same lowercase letter in the rows and uppercase in the columns do not differ statistically by the Scott and Knott test $(\mathrm{P}>0.05)$.

*Number and timing of treatment applications: $(1$ - September; 2 - September and November; 3 - September, November and January).

The $P$. chlamydosporia-based biological nematicide, when applied alone, proved to be effective in the management of $M$. incognita race 1 , as it provided a decrease in FP in coffee roots in the November and March evaluations, with 1 and 2 applications compared to the control. It also reduced soil FP in all evaluation periods with 3 applications (Table 2). This antagonist, when applied 2 or 3 times, in the January evaluation, proved to be more efficient than the chemical nematicide in reducing the NFP in the roots, proving the efficiency of this biological control agent, as well as its potential use in the management of $M$. incognita race 1 (Table 2).

Regarding the evaluation period, $P$. chlamydosporia was responsible for the largest reduction in soil NFP in January with 1 application and in March with 3 applications (Table 2). Other authors have shown that $P$. clamydosporia isolate Pc-10 is an efficient biocontrol agent of Meloidogyne spp. in other crops (DIAS-ARIEIRA et al., 2011; VIGGIANO; FREITAS; LOPES, 2014). One, two and three applications of $P$. chlamydosporia + $T$. harzianum reduced the FP in all evaluations when compared to the control (Table 2). In general, the associated use of the fungi $P$. chlamydosporia and T. harzianum showed results statistically equal to or close to those of their isolated uses in nematode population reduction.

The association between $P$. chlamydosporia + T. harzianum provided lower values of $\mathrm{J} 2$ in soil in 
relation to the control, with the lowest value found with one application in November. In this case, this ws the treatment that most reduced the soil NFP with one single application (Table 2).

Induction of soil suppressivity by the use of combinations of two or more antagonist organisms may provide better disease management compared to the use of individually applied organisms (MACHADO et al., 2012). Several organisms may enhance the efficiency of biological control due to their different mechanisms of action. Combinations can provide protection at different times or under different conditions and occupy different or complementary niches (SRIVASTAVA et al., 2010).

Based on the parasitism mechanism of eggs and females exerted by $P$. chlamydosporia and substance release antagonism by $T$. harzianum, the application of the two biocontrol agents at different times of the phenological cycle could increase the management efficiency during the longest period of nutrient drainage by coffee. This is the postflowering and grain-filling period, and is also the most favorable time for the nematode, due to the occurrence of higher soil moisture and temperature.

\section{Damage Quantification}

In the evaluations of the quantitative characteristics of the harvested grains, there was a difference between the averages obtained from plants treated with biological and chemical nematicides, and WG100 was the most influenced variable (Table 3).

Table 3. Number of fruits per rosette (NFPR), total grain weight per rosette (TGWR), weight of 100 processed grains (WG100), processed/mature yield (PMY\%), yield in bags per hectare (YBHa) and yield value (YVU\$) of Conilon coffee clone V02, from the variety "Vitória" INCAPER 8142, submitted to different management methods of Meloidogyne incognita race 1 under evaluation in March 2014.

\begin{tabular}{lcccccc}
\hline & \multicolumn{5}{c}{ Variables analyzed } \\
\cline { 2 - 7 } \multicolumn{1}{c}{ Treatments } & NFPR & $\begin{array}{c}\text { TGWR } \\
\text { Control }\end{array}$ & WG100 $(\mathrm{g})$ & PMY\% & YBHa & YVU\$ \\
\hline \multicolumn{1}{c}{$19.25 \mathrm{~A}^{1}$} & $13.60 \mathrm{~A}^{1}$ & $13.23 \mathrm{~A}$ & $35.38 \mathrm{D}^{2}$ & $73.63 \mathrm{~A}^{1}$ & $4,178.405 \mathrm{~A}^{2}$ \\
Carbofuran: $50 \mathrm{~g} / \mathrm{kg} \mathrm{1*}$ & $32.00 \mathrm{C}$ & $21.00 \mathrm{~B}$ & $16.29 \mathrm{C}$ & $35.50 \mathrm{D}$ & $155.56 \mathrm{D}$ & $8,828.17 \mathrm{D}$ \\
Carbofuran: $50 \mathrm{~g} / \mathrm{kg} \mathrm{2}$ & $30.25 \mathrm{~B}$ & $27.25 \mathrm{C}$ & $17.33 \mathrm{D}$ & $39.33 \mathrm{E}$ & $197.02 \mathrm{~F}$ & $11,180.74 \mathrm{~F}$ \\
Carbofuran: $50 \mathrm{~g} / \mathrm{kg} \mathrm{3}$ & $29.25 \mathrm{~B}$ & $29.17 \mathrm{D}$ & $16.60 \mathrm{C}$ & $32.58 \mathrm{~B}$ & $170.47 \mathrm{E}$ & $9,673.935 \mathrm{D}$ \\
T. harzianum: 1 & $27.50 \mathrm{~B}$ & $28.22 \mathrm{D}$ & $15.49 \mathrm{~B}$ & $31.58 \mathrm{D}$ & $156.77 \mathrm{D}$ & $8,894.555 \mathrm{D}$ \\
T. harzianum: 2 & $25.75 \mathrm{~B}$ & $22.15 \mathrm{~B}$ & $18.28 \mathrm{~F}$ & $38.38 \mathrm{E}$ & $120.07 \mathrm{~B}$ & $6,814.17 \mathrm{~B}$ \\
T. harzianum: 3 & $26.00 \mathrm{~B}$ & $23.95 \mathrm{C}$ & $18.59 \mathrm{~F}$ & $38.88 \mathrm{E}$ & $157.48 \mathrm{D}$ & $8,934.585 \mathrm{D}$ \\
P. chlamydosporia: 1 & $33.75 \mathrm{C}$ & $26.62 \mathrm{C}$ & $17.71 \mathrm{E}$ & $32.09 \mathrm{~B}$ & $160.33 \mathrm{D}$ & $9,098.687 \mathrm{D}$ \\
P. chlamydosporia: 2 & $29.25 \mathrm{~B}$ & $28.95 \mathrm{D}$ & $17.34 \mathrm{D}$ & $31.86 \mathrm{~B}$ & $115.16 \mathrm{~B}$ & $6,535.05 \mathrm{~B}$ \\
P. chlamydosporia: 3 & $38.00 \mathrm{D}$ & $24.62 \mathrm{C}$ & $17.17 \mathrm{D}$ & $35.96 \mathrm{D}$ & $154.42 \mathrm{D}$ & $8,763.057 \mathrm{D}$ \\
P. chlamydosporia + T. harzianum: 1 & $27.00 \mathrm{~B}$ & $26.72 \mathrm{C}$ & $16.04 \mathrm{~B}$ & $35.96 \mathrm{~B}$ & $137.57 \mathrm{C}$ & $7,806.9 \mathrm{C}$ \\
P. chlamydosporia + T. harzianum: 2 & $37.75 \mathrm{D}$ & $24.52 \mathrm{C}$ & $17.88 \mathrm{E}$ & $34.31 \mathrm{C}$ & $143.05 \mathrm{C}$ & $8,117.87 \mathrm{~B}$ \\
P. chlamydosporia + T. harzianum: 3 & $29.25 \mathrm{~B}$ & $32.27 \mathrm{D}$ & $17.85 \mathrm{E}$ & $29.03 \mathrm{~A}$ & $133.75 \mathrm{C}$ & $7,657.995 \mathrm{C}$ \\
\hline
\end{tabular}

${ }^{1}$ Averages followed by the same capital letter in the columns do not differ statistically by the Scott and Knott test $(\mathrm{P}>0.05)$.

${ }^{2}$ Values obtained by dividing the amount of processed coffee obtained per kilogram of properly dried mature coffee with a moisture content of $12.00 \%$.

*Number of applications.

The NFPR was influenced by the treatments, and the untreated plants (control) presented the lowest value. Thus, the quantitative damage caused by $M$. incognita race 1 is evident, as the lower weight per benefited grain indicates the use of a smaller sieve and the need for more grains to compose a $60 \mathrm{~kg}$ bag, which may compromise the profitability of the producer at sale time.

The highest NFPR values were observed in plants that received three applications of
P. chlamydosporia and two applications of P. chlamydosporia $+T$. harzianum (Table 3 ).

The TGWR had its lowest value in the control. The highest averages were obtained with three applications of $P$. chlamydosporia $+T$. harzianum, two applications of $P$. chlamydosporia, one application of $T$. harzianum and three applications of Carbofuran (Table 2).

The highest averages of WG100 were obtained with two and three applications of 
T. harzianum and three applications of Carbofuran (Table 3).

PMY\% was lower in plants that received three associated applications of $P$. chlamydosporia + T. harzianum $(29.03 \%)$, which indicates that for each $1000 \mathrm{~g}$ of mature coffee, $290.30 \mathrm{~g}$ of processed coffee is obtained (Table 3 ).

The highest YBHa were obtained with two and three applications of Carbofuran (Table 3). This is due to the fact that these two treatments were the ones that most reduced FP at harvest in March (Table 2). Another possible explanation for the higher productivity caused by the application of chemical nematicide is the prophylactic effects of carbofuran, which stimulate plant growth and consequently its resistance (SINGH; VARSHNEYA; SRIVASTAVAB, 2012).

The yield value (YVU \$) was higher than the control in all management strategies tested, with the highest values being obtained with one, two and three applications of Carbofuran, one and three applications of $P$. chlamydosporia and T. harzianum (Table 3).

Untreated (control) plants produced $73.63 \mathrm{sc} /$ ha (Table 3 ), which is not a low yield for the cultivar 'Vitória INCAPER 8142' clone V02. This good yield may be explained by the fact that the crop in which the research was carried out followed the technical recommendations of nutrition, irrigation and pest and disease management. However, as $M$. incognita is a new challenge for many Espírito Santo coffee growers (BARROS et al., 2014), the non-use of efficient methods of crop management can cause a reduction in conilon coffee productivity due to plant parasitism by the nematode.

Young plants are the most damaged, although adult plants can also suffer serious defoliation, impairing the production of photoassimilates important for production (SALGADO et al., 2015). It is worth remembering that plants that receive good nutrition are more likely to resist nematode attack than nutrient-deficient plants (SANTANA-GOMES et al., 2013).

The results regarding damage caused by $M$. incognita race 1 found in this research corroborate those from the study of Oliveira et al. (2009), in a commercial crop of 'Vitória INCAPER 8142', clone V02 conilon coffee variety, infested with $M$. incognita in the municipality of Sooretama, Espírito Santo, Brazil. That study found root deformation, cracking, scaling and displacement of cortical root tissues in plants attacked by the pathogen. According to the authors, due to the damage caused by the nematodes, the plants started to exhibit a high number of fruits classified as black and dry. Other damage was also attributed to parasitism, such as: reductions in plant height, number of leaves, productive and vegetative branches and rosettes per branch.

The quality of the benefited coffee regarding the grain size was influenced by the management method, as well as the number of applications of each treatment. For conilon coffee, the ideal is that the benefited grains have the highest percentage above sieve 13 , as this ensures a higher yield and, consequently, market price.

\section{Yield Loss Quantification}

The highest application costs of management methods for $M$. incognita race 1 per hectare were: U\$ 680.46 and U\$ 453.50 for three and two applications of Carbofuran and U\$ 322.50 for three applications of $P$. chlamydosporia $+T$. harzianum (Table 4).

The treatments with lowest application costs were U\$ 47.50 for one application of $T$. harzianum and U\$ 72.50 for one application of $P$. chlamydosporia (Table 4).

Increasing the population of $M$. incognita race 1 at harvest led to reduced yield (Figure 1). Comparing the management costs (Table 4) with the NFP on the coffee roots in the March evaluation (Figure 1), it was possible to verify that $P$. chlamydosporia and $T$. harzianum fungi, applied alone, presented the best results for cost/benefit, because they are more economical and also proved to be efficient in the management of the nematode.

The use of Carbofuran, despite being efficient in the management of $M$. incognita race 1, presented a low cost/benefit, that is, it is a relatively expensive method for the producer and presents risks of environmental pollution (NASR, 2015).

These results of application costs, linked to the management of $M$. incognita race 1 , are extremely important for coffee growing, because the management strategies tested, both biological and chemical, demonstrated management efficiency under the studied conditions. However, it is known that each of them has a cost to the producer, and their adoption should be based mainly on the pillars of phytosanitary management of plant diseases, which aims at environmental, economic and social sustainability, but must also have a holistic view of the agroecosystem.

The management methods that influenced the increase in the quality of the grains harvested in the experiment, which led to obtaining the highest percentages of coffee grains retained in sieves $\geq 13$, were one and two applications of $P$. chlamydosporia (Table 5). 
Table 4. Recommended dose (DOS), unit price (UNP), price of the commercial quantity used (CQU) and application costs (APC) and total cost (TCO) of each treatment for management of $M$. incognita race 1 in conilon coffee clone V02 variety 'Vitória INCAPER 8142', in a field cultivated in the region of São Roque do Canaã, ES, naturally infested by the nematode.

\begin{tabular}{|c|c|c|c|c|c|}
\hline \multirow[b]{2}{*}{ Treatments } & \multicolumn{5}{|c|}{ Variables analyzed } \\
\hline & $\begin{array}{c}\text { DOS } \\
(\mathrm{kg} \text { or } \mathrm{L} / \mathrm{ha})\end{array}$ & $\begin{array}{l}\text { UNP } \\
\text { (U\$) }\end{array}$ & CQU & $\begin{array}{c}\text { APC } \\
(\mathrm{U} \$ / \mathrm{ha})^{4}\end{array}$ & TCO (U\$/ha) \\
\hline Control & 0 & 0 & 0 & 0 & 0 \\
\hline Carbofuran: $50 \mathrm{~g} / \mathrm{kg} 1^{*}$ & $89.34 \mathrm{~kg} / \mathrm{ha}^{1}$ & 24.00 & 2.23 & 12.50 & 226.82 \\
\hline Carbofuran: $50 \mathrm{~g} / \mathrm{kg} 2$ & $178.68 \mathrm{~kg} / \mathrm{ha}$ & 24.00 & 4.46 & 25.00 & 453.50 \\
\hline Carbofuran: $50 \mathrm{~g} / \mathrm{kg} 3$ & $268.02 \mathrm{~kg} / \mathrm{ha}$ & 24.00 & 6.69 & 37.50 & 680.46 \\
\hline T. harzianum: 1 & $1.00 \mathrm{l} / \mathrm{ha}^{2}$ & 35.00 & 0.25 & 12.50 & 47.50 \\
\hline T. harzianum: 2 & $2.00 \mathrm{l} / \mathrm{ha}$ & 35.00 & 0.5 & 25.00 & 95.00 \\
\hline T. harzianum: 3 & 3.00 1/ha & 35.00 & 0.75 & 37.50 & 142.50 \\
\hline P. chlamydosporia: 1 & $2.00 \mathrm{~kg} / \mathrm{ha}^{3}$ & 60.00 & 0.25 & 12.50 & 72.50 \\
\hline P. chlamydosporia: 2 & $4.00 \mathrm{~kg} / \mathrm{ha}$ & 60.00 & 0.5 & 25.00 & 145.00 \\
\hline P. chlamydosporia: 3 & $6.00 \mathrm{~kg} / \mathrm{ha}$ & 60.00 & 0.75 & 37.50 & 217.50 \\
\hline P. chlamydosporia + T. harzianum: 1 & $2.00 \mathrm{~kg} / \mathrm{ha}+1.00 \mathrm{l} / \mathrm{ha}$ & $60.00+35.00$ & $0.25+0.25$ & 12.50 & 107.50 \\
\hline P. chlamydosporia + T. harzianum: 2 & $4.00 \mathrm{~kg} / \mathrm{ha}+2.00 \mathrm{l} / \mathrm{ha}$ & $60.00+35.00$ & $0.5+0.5$ & 25.00 & 215.00 \\
\hline P. chlamydosporia + T. harzianum: 3 & $6.00 \mathrm{~kg} / \mathrm{ha}+3.00 \mathrm{l} / \mathrm{ha}$ & $60.00+35.00$ & $0.75+0.75$ & 37.50 & 322.50 \\
\hline
\end{tabular}

${ }^{1}$ Recommendations for coffee: source: (AGROFIT, 2013), $30.00 \mathrm{~g}$ per plant (recommendation: $2978 \mathrm{plant} / \mathrm{ha} \mathrm{x} 0.030 \mathrm{~kg}$ plant: $89.34 \mathrm{~kg} / \mathrm{ha}$ ). Furadan ${ }^{\circledR} 50 \mathrm{GR}$, average price per bag of 10 pounds in Espírito Santo: U\$ 24.00. ${ }^{2}$ Recommendations for coffee: source: (KOPPERT, 2013), 1.00 1/ha. Trichodermil ${ }^{\circledR}$ SC, strain ESALQ 1306, average price per pack of 1 liter in Espírito Santo: U\$ 35.00. ${ }^{3}$ Recommendations for coffee: source: (RIZOFLORA, 2013), $2.00 \mathrm{~kg} / \mathrm{ha}$. Rizotec ${ }^{\mathbb{B}}$ Insulated Pc10, average price per pack of $2 \mathrm{~kg}$ in Espírito Santo: U\$ 60.00. ${ }^{4}$ Application cost based on the monetary value of U\$ 12.50 for 1 work-day of 1 rural worker in the studied region, establishing that the worker spends 1 day on each application in 1 ha. *Number of applications.

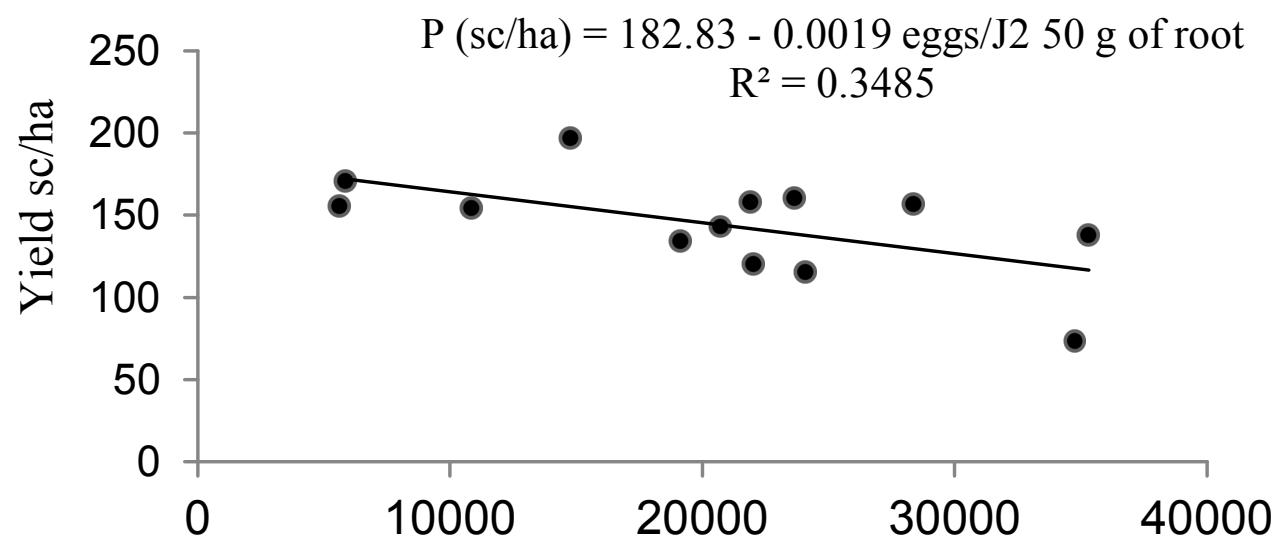

\section{Population of $M$. incognita race 1 per $50 \mathrm{~g} / \mathrm{root}$}

Figure 1. Relationship between yield of conilon coffee variety 'Vitória INCAPER 8142' clone V02 and different populations of Meloidogyne incognita race 1 found in field treatments (evaluation in March 2014). 
Table 5. Percentage of grains benefited removed in sieves $\geq 13$, residue (sieve $\leq 13$ ), yield value (YVA), total production custody (TCP) and liquid yield (JNI) of clone V02, variety 'Vitória INCAPER 8142', subject to different management methods for Meloidogyne incognita race 1.

\begin{tabular}{|c|c|c|c|c|c|}
\hline \multirow[b]{2}{*}{ Treatments } & \multicolumn{5}{|c|}{ Variables analyzed } \\
\hline & Sieve $\geq 13(\%)$ & residue $(\%)$ & $\begin{array}{l}\text { (YVA) } \\
\text { U\$/ha) }\end{array}$ & $\begin{array}{c}\text { (CTP) } \\
\text { (U\$/ha) }\end{array}$ & $\begin{array}{c}\text { GLP } \\
\text { (U\$/ha) }\end{array}$ \\
\hline Control & $70.10 \mathrm{C}$ & $29.90 \mathrm{C}$ & $4.178 .40 \mathrm{~A}^{1}$ & 0 & $4.178 .40 \mathrm{~A}^{1}$ \\
\hline Carbofuran: $50 \mathrm{~g} / \mathrm{kg} 1^{*}$ & $81.10 \mathrm{~B}$ & $18.90 \mathrm{~B}$ & 8.828.17 D & 453.56 & $8.601 .35 \mathrm{D}$ \\
\hline Carbofuran: $50 \mathrm{~g} / \mathrm{kg} 2$ & $80.00 \mathrm{~B}$ & $20.00 \mathrm{~B}$ & $11.180 .50 \mathrm{~F}$ & 680.46 & 10.727.10 E \\
\hline Carbofuran: $50 \mathrm{~g} / \mathrm{kg} 3$ & $81.45 \mathrm{~B}$ & $18.55 \mathrm{~B}$ & $9.673 .93 \mathrm{E}$ & 226.75 & 8.993.47 D \\
\hline Trichoderma harzianum: 1 & $68.77 \mathrm{D}$ & $31.23 \mathrm{D}$ & 8.896.80 D & 47.50 & $8.849 .30 \mathrm{D}$ \\
\hline T. harzianum: 2 & $82.20 \mathrm{~B}$ & $17.80 \mathrm{~B}$ & 6.814.17 B & 95.00 & $6.719 .17 \mathrm{~B}$ \\
\hline T. harzianum: 3 & $76.55 \mathrm{~B}$ & $23.45 \mathrm{~B}$ & 8.934.58 D & 142.50 & $8.292 .08 \mathrm{D}$ \\
\hline Pochonia chlamydosporia: 1 & $85.60 \mathrm{~A}$ & $14.40 \mathrm{~A}$ & $9.098 .68 \mathrm{D}$ & 72.50 & $9.026 .18 \mathrm{D}$ \\
\hline P. chlamydosporia: 2 & $86.00 \mathrm{~A}$ & $14.00 \mathrm{~A}$ & $6.535 .05 \mathrm{~B}$ & 145.00 & $6.390 .05 \mathrm{~B}$ \\
\hline P. chlamydosporia: 3 & $78.20 \mathrm{~B}$ & $21.80 \mathrm{~B}$ & $8.763 .05 \mathrm{D}$ & 217.50 & $8.545 .55 \mathrm{D}$ \\
\hline P. chlamydosporia + T. harzianum: 1 & $68.90 \mathrm{D}$ & $31.10 \mathrm{D}$ & $7.806 .90 \mathrm{C}$ & 107.50 & 7.699.40 C \\
\hline P. chlamydosporia + T. harzianum: 2 & $83.54 \mathrm{~B}$ & $16.46 \mathrm{~B}$ & $8.117 .96 \mathrm{C}$ & 215.00 & 7.902.87 C \\
\hline P. chlamydosporia + T. harzianum: 3 & $80.00 \mathrm{~B}$ & $20.00 \mathrm{~B}$ & 7.657.99 C & 322.50 & 7.335.49 C \\
\hline
\end{tabular}

${ }^{1}$ Averages followed by the same capital letter in the columns do not differ statistically by the Scott and Knott test $(\mathrm{P}>0.05)$. *Number of applications.

The treatments with the lowest percentage of coffee grains retained in sieves $\geq 13$ were: control; one application of $P$. chlamydosporia + $T$. harzianum and one application of T. harzianum (Table 4). This may be related to the fact that the association of $P$. chlamydosporia $+T$. harzianum in a single application, as well as one application of T. harzianum, did not exert management effectiveness, as observed in the other treatments, which led to an increase in productive and qualitative damage to grains from plants that received these treatments (Tables 2, 3 and 4).

The percentage of coffee grains retained in sieves $\geq 13$ obtained in the unmanaged area of $M$. incognita race 1 is related to the interference caused by nematodes in plant development. This interference is related to nutrient spoliation during nematode feeding (FORTI et al., 2015); change in absorption and translocation of water and nutrients; modification or destruction and decrease of the roots, resulting in symptoms of the shoot, such as yellowing (CARVALHO et al., 2015); and reduction of the size and smaller proportion between shoot weight and root system.

The production value was calculated as a function of productivity in bags benefited per hectare obtained in each treatment, with the producer's gross revenue being influenced by the tested management method. The sale of the production obtained in the control would result in a gross production value of U\$ 4,178.40, which is low compared to the
U\$ $11,180.74$ obtained with two nematicide applications (Table 4).

All treatments increased the average yield of the crop because the soil addition of antagonists to $M$. incognita race 1 or nematicide caused a decrease in the root and soil pathogen population, resulting in gains in average coffee yield (SRIVASTAVA et al. 2010; MACHADO et al., 2012).

The TCO was higher in all treatments than in the control, and the highest values were obtained with one, two and three applications of carbofuran, one and three applications of $P$. chlamydosporia and two and three applications of $P$. chlamydosporia + T. harzianum (Table 4).

The initial population of $M$. incognita race 1 already established in the field at the begining of the the experiment was 3,000 eggs $+\mathrm{J} 2 / 50 \mathrm{~g}$ of roots. The plants were 24 months old with a fully developing root system and plenty of food available for the nematode, which contributed to a significant increase in its population over the following months (TAYLOR; SASSER, 1978) (Table 2).

In the present research, the lowest yields, total grain weight per rosette, weight of 100 processed grains and percentage of processed coffee grains retained in sieves $\geq 13$ were caused by the largest populations of $M$. incognita race 1 in the roots and soil (Tables 3 and 4). Plants that were not submitted to any management method (control) during the productive cycle (September-March) presented the greatest damage caused by the nematode. 
The severity of damage caused by parasitism of Meloidogyne spp. in coffee is directly related to the number of root-eating individuals, which influences the physiological processes of the plant and culminates in dwarfism, nutritional deficiencies or toxicity, wilting, and reduced yields (ROSELI et al., 2019). All these types of damage were observed in our research, highlighting the decrease in the number of fruits in the rosettes and the fall of leaves.

\section{CONCLUSIONS}

We conclude that all treatments are efficient for the management of $M$. incognita race 1 in brown coffee, causing a reduction in root population in isolation. However, there is no management measure implemented, or performance and damage not large or sufficient nematode parasitism. Finally, the fungi $P$. chlamydosporia var. chlamydosporia and T. harzianum, tested in isolation and in combination, were efficient biological methods I do not administer to breed $M$. incognita 1 .

\section{REFERENCES}

ABD-ELGAWARD, M. M. M.; ASKARY, T. H. Impact of phytonematodes on agriculture economy. In. ASKARY, T. H.; MARTINELLI, R. P. (Eds.) Biocontrol agents of phytonematodes. Boston, EUA, CAB International. 2015. cap. 1, p. 3-49.

AGROFIT. Recomendações para produtos fitossanitários. Ministério da Agricultura Pecuária e Abastecimento-MAPA, Brasília, 03 set. 2013. Disponível em:< http://extranet.agricultura.gov.br/ agrofit_cons/principal_agrofit_cons $>$. Acesso em: 20 out. $20 \overline{2} 0$.

ANDROCIOLI FILHO, A.; ANDROCIOLI, L. G. Adensamento e poda do café arábica no Espírito Santo. In: TOMAZ, M. A. et al. (Eds.). Tecnologias para a sustentabilidade da cafeicultura. Centro de Ciências Agrárias, Alegre, ES: 2011. v. 1, p. 69- 94.

BARROS, A. F.et al. Root-knot nematodes, a growing problem for Conilon coffee in Espírito Santo state, Brazil. Crop Protection, 55: 74-79, 2014.

BONETTI, J. I. S.; FERRAZ, S. Modificações do método de Hussey \& Barker para extração de ovos de Meloidogyne exigua em raízes de cafeeiro. Fitopatologia Brasileira, 6: 553, 1981.

BRASIL. Ministério da Agricultura, Pecuária e Abastecimento. Regulamento técnico de identidade e de qualidade para a classificação do café beneficiado grão cru. Instrução Normativa $n^{\circ} 8$, de 11 de junho de 2003. 11 p.

CARNEIRO, R. M. D. G.; ALMEIDA, M. R. A. Técnica de eletroforese usada no estudo de enzimas dos nematoides das galhas para identificação de espécies. Nematologia Brasileira, 25: 35-44, 2001.

CARVALHO, J. P. F. et al. Dinâmica de macronutrientes em genótipos de Coffea canephora com potencial para utilização como porta-enxerto. Coffee Science, 10: 176 - 183, 2015.

CONAB - Companhia Nacional de Abastecimento. Acompanhamento da safra brasileira de café: monitoramento agrícola - café - safra 2017, 1: 1-98, 2017.

CONTARATO, C. et al. Reaction of cultivar coffee 'Vitória INCAPER 8142' of conillon to parasitism of Meloidogyne exigua. Idesia, 32: 93-97, 2014.

COOPEAVI - Cooperativa Agropecuária Centro Cerrana. Preço médio do Furadan ${ }^{\circledR} 50$ GR. Cooperativa Agropecuária Centro Cerrana, Santa Maria de Jetibá, ES, 03 jan. 2015. Disponível em: $<$ http://www.coopeavi.coop.br/?consultoria-tecnica $>$. Acesso em: 03 jan. 2015.

DIAS-ARIEIRA, C. R. et al. Efficiency of Pochonia chlamydosporia in Meloidogyne incognita control in lettuce crop (Lactuca sativa L.). Journal of Food, Agriculture \& Environment, 9: 561-563, 2011.

ESCOBAR, C. et al. Overview of root-knot nematodes and giant cells. Advances in botanical research, 1: 1-32, 2015.

FORTI, V. A. et al. Meloidogyne javanica infection of soybean plants: plant response, seed quality and green seeds occurrence. Seed Science and Technology, 43: 1-12, 2015.

HARTMAN, K. M.; J. N. SASSER. Identification of Meloidogyne species on the basis of differential host test and perineal-pattern morphology. In: BARKER, K. R.; CARTER, C. C.; SASSER, J. N. Advanced treatise on Meloidogyne. Methodology. North Carolina, USA: University Graphics, Raleigh, 1985, p. 69-77.

HOWELL, C. R. et al. Induction of terpenoid synthesis in cotton roots and control of Rhizoctonia solani by seed treatment with Trichoderma virens. Phytopathology, 90: 248-252, 2000.

HUSSEY, R. S; BARKER, K. R. A comparison of methods of collecting inocula of Meloidogyne spp. including a new technique. Plant Disease Reporter, 57: 1025-1028, 1973. 
JENKINS, W. R. A rapid centrifugal-flotation technique for separating nematodes from soil. Plant Disease Reporter, 48: 692, 1964.

KOPPERT - Koppert Biological Systems. Trichodermil I306 - Controle biológico e manejo de doenças na agricultura. 2013. 2 p.

MACHADO, D. F. M. et al. Trichoderma no Brasil: o fungo e o bioagente. Revista de Ciências Agrárias, 35: 274-288, 2012.

MENDOZA, J. L. H. et al. Antibiosis of Trichoderma spp strains native to northeastern Mexico against the pathogenic fungus Macrophomina phaseolina. Brazilian Journal of Microbiology, 46: 1093-1101, 2015.

MOENS, M.; PERRY, R. N.; STARR, J. L. Meloidogyne Species - a diverse group of novel and importante plant parasites. In: PERRY, R. N.; MOENS, M.; STARR, J. L. (Eds). Root-knot nematodes. Cambridge, MA, USA: CABI North America Office. 2009. p. 1-17.

NASR, H. M. Toxicity and biochemical effect of organophosphates and bio-pesticides against rootknot nematode, Meloidogyne incognita. Journal of Pollution Effects \& Control, 4: 1-9, 2015.

OLIVEIRA, D. S. et al. Characterization of Meloidogyne incognita populations from São Paulo and Minas Gerais state and their pathogenicity on coffee plants. Tropical Plant Pathology, 36: 190194, 2011.

OLIVEIRA. D. S. et al. Falha na adaptabilidade de Meloidogyne incognita ao cafeeiro. Nematologia Brasileira, 33: 207-211, 2009.

RIZOFLORA. Uso de RIZOTEC ${ }^{\circledR}$ no controle de doenças. Rizoflora Tecnologia, Viçosa, 09 set. 2013. Disponível em: http://www.rizoflora.com.br/. Acesso em: 09 set. 2013.

RODRIGUES, L. L. et al. Management of Meloidogyne javanica with biological pesticides and oils in a lettuce field. Nematoda, 3: 1-9, 2016.

ROSELI, G. R. et al. Meloidogyne paranaensis and $M$. exigua alter coffee physiology. Nematology, 21: 459-467, 2019.

SALGADO, S. M. L. et al. Meloidogyne paranaensis e Meloidogyne exigua em lavouras cafeeiras na região sul de minas gerais. Coffee Science, 10: 475-481, 2015.
SANTANA-GOMES, S. M. et al. Mineral nutrition in the control of nematodes. African Journal of Agricultural Research, 8: 2413-2413, 2013.

SILVA, R. V. et al. Effects of silicon on the penetration and reproduction events of Meloidogyne exigua on coffee roots. Bragantia, 74: 196-199, 2015.

SINGH, R. P.; VARSHNEYA, G.; SRIVASTAVAB, G. Effect of carbofuran on enzymatic activities and growth of tomato plants in natural, fertilized and vermicompost-amended soils. Archives of Agronomy and Soil Science, 58: 13491364, 2012

SRIVASTAVA, R. et al. Evaluation of arbuscular mycorrhizal fungus, fluorescente Pseudomonas and Trichoderma harzianum formulation against Fusarium oxysporum f. sp. lycopersici for the management of tomato wilt. Biological Control, 53: 24-31, 2010.

TAYLOR, A. L.; SASSER J. N. Biology, identification and control of root-knot nematodes (Meloidogyne spp.). North Carolina State University, Raleigh: Department of plant pathology north carolina state university and the united states agency for international development, $1978.111 \mathrm{p}$.

VIGGIANO, J. R.; FREITAS, L. G.; LOPES, E. A. Use of Pochonia chlamydosporia to control Meloidogyne javanica in cucumber. Biological Control, 69: 72-77, 2014. 